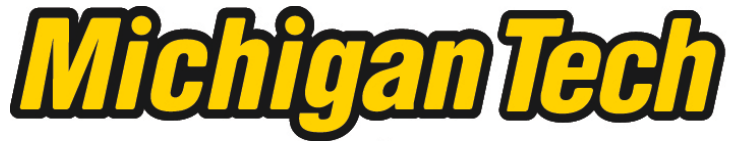 \\ Michigan Technological University Create the Future Digital Commons @ Michigan Tech
}

Erupted magma volume estimates at Santiaguito and Pacaya Volcanoes, Guatemala using digital elevation models

Kelly S. Durst

Michigan Technological University

Follow this and additional works at: https://digitalcommons.mtu.edu/etds

Part of the Geology Commons

Copyright 2008 Kelly S. Durst

\section{Recommended Citation}

Durst, Kelly S., "Erupted magma volume estimates at Santiaguito and Pacaya Volcanoes, Guatemala using digital elevation models ", Master's Thesis, Michigan Technological University, 2008.

https://doi.org/10.37099/mtu.dc.etds/318

Follow this and additional works at: https://digitalcommons.mtu.edu/etds

Part of the Geology Commons 


\title{
Erupted Magma Volume Estimates at Santiaguito and Pacaya Volcanoes, Guatemala using Digital Elevation Models
}

\author{
By: Kelly S. Durst
}

\author{
A THESIS \\ Submitted in partial fulfillment of the requirements \\ for the degree of \\ MASTER OF SCIENCE IN GEOLOGY
}

MICHIGAN TECHNOLOGICAL UNIVERSITY

2008

Copyright @ Kelly S. Durst 2008 
This Thesis "Erupted Magma Volume estimates at Santiaguito and Pacaya volcanoes, Guatemala using digital elevation models" is hereby approved in partial fulfillment of the requirements for the Degree of MASTER OF SCIENCE IN GEOLOGY.

DEPARTMENT:

Geological and Mining Engineering and Sciences

Signatures:

Thesis Advisor

Dr. William I. Rose

Department Chair

Dr. Wayne Pennington

Date: 


\section{Acknowledgments}

I have wanted to study volcanology since I took my first geology course 13 years ago. There are many people I would like to thank which got me to this point and enabled me to travel and see many wonderful volcanoes. First I would like to thank Dr. William Rose for advising me and being an excellent reviewer for my many drafts. I would also like to thank my committee members, Dr. Ann Maclean, who has helped me so much since I have been here; I cannot thank her enough for the encouragement she has given me. My third committee member, Matt Patrick, has given me helpful reviews and has always been there whenever I had the smallest question. There are many other people who helped me and without them this research would never have been completed. These include Dr. Steve Schilling for his GIS data and help, Dr. Gerard Heuvelink for giving me error ideas, without which I would not have been able to complete the thesis, Dr. Robert Froese for always having an open door for statistics help, Rüdiger Escobar Wolf; without his help I would never be in this position, he has been invaluable in helping with this research, and Miriam Rios-Sanchez, for her much appreciated help with geostatistics. I would like to thank the National Science Foundation, MTU Remote Sensing Institute and the Geology department for funding my research. Thanks to my friends in Houghton and those living in Ohio, Virginia, and elsewhere that have always supported me and are always there to listen when I needed to talk. My family who mean the world to me and have always supported me no matter what. Thanks to everyone that has enabled me to get here; your friendship and support have meant everything to me! 


\section{Table of Contents}

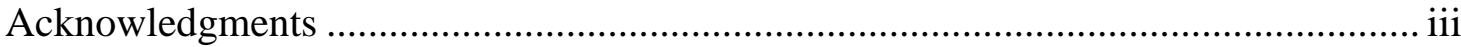

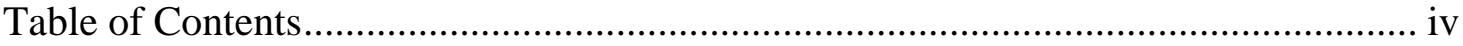

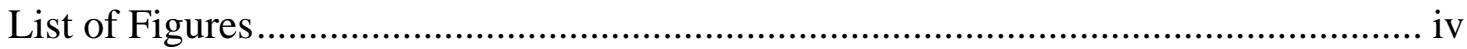

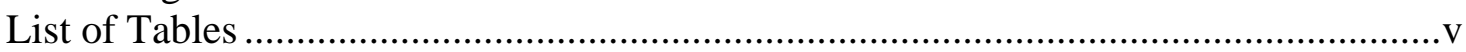

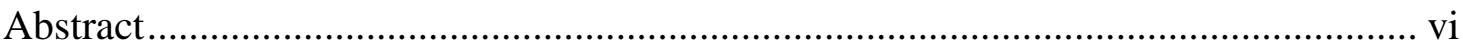

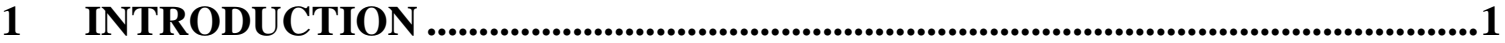

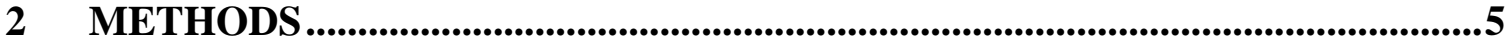

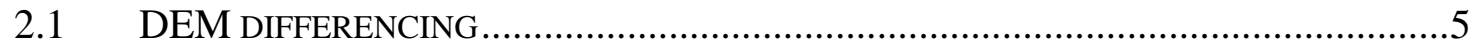

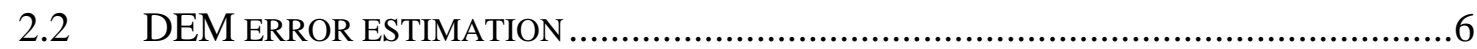

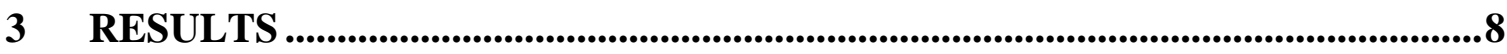

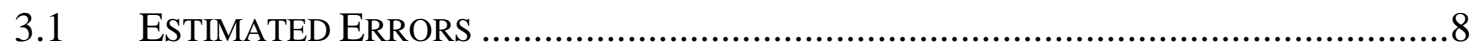

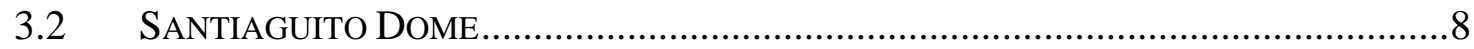

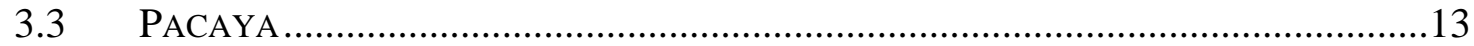

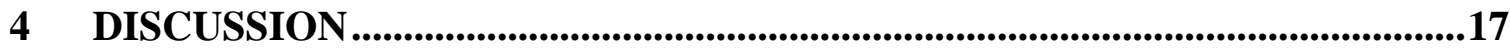

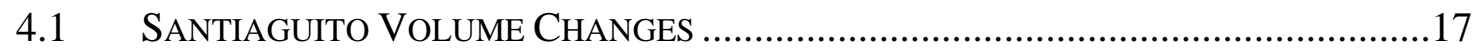

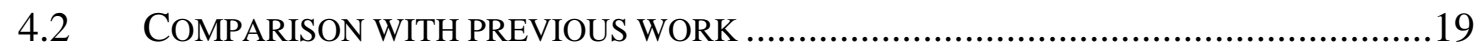

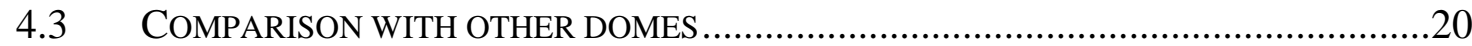

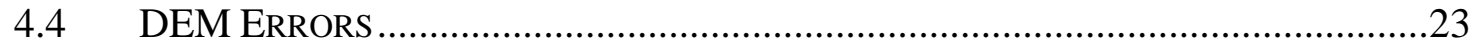

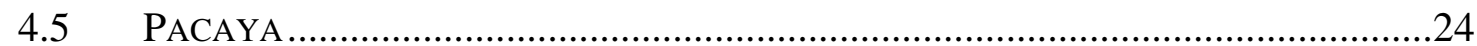

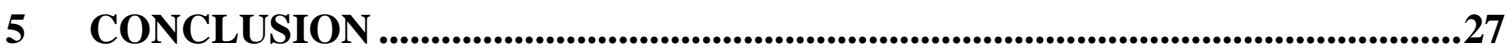

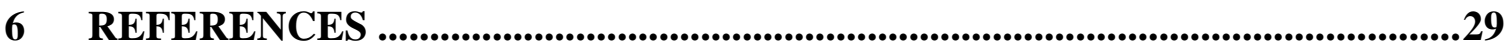

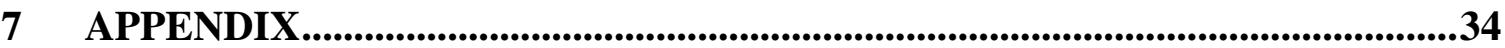

\section{List of Figures}

Figure 1.1 Map of Guatemala with Santa María/Santiaguito and Pacaya Volcanoes ........1

Figure 3.1 Elevation change map for the Santiaguito dome........................................10

Figure 3.2 Elevation change map outside of the dome...................................................11

Figure 3.5 Elevation change map of Pacaya volcano..................................................15

Figure 3.6 Map of elevation change outside of the Pacaya region .................................16

Figure 4.1 Elevation change map for Santiaguito with lava flows units .........................18

Figure 4.2 Extrusion rates for various volcanic domes over eruption duration................22

Figure 4.3 Extrusion rates for various volcanic domes over eruption duration................26 


\section{List of Tables}

Table 3-1 Table showing RMSE for each DEM. ........................................................8

Table 3-2 Table showing mean elevation change for the dome and the region outside......9

Table 3-3 Summary Table for DEM error, Area, and Volume Change. ............................12

Table 3-5 Table showing overall DEM error ..............................................................14

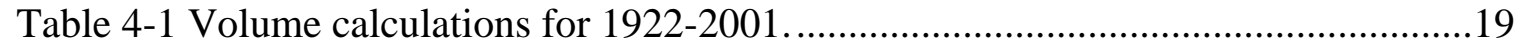

Table 4-2 Volume and extrusion rates for various volcanic domes ...............................21

Table 4-3 Lava volume and extrusion rates for basaltic volcanoes ..................................25 


\section{Abstract}

High resolution digital elevation models (DEMs) of Santiaguito and Pacaya volcanoes, Guatemala, were used to estimate volume changes and eruption rates between 1954 and 2001. The DEMs were generated from contour maps and aerial photography, which were analyzed in ArcGIS 9.0®. Because both volcanoes were growing substantially over the five decade period, they provide a good data set for exploring effective methodology for estimating volume changes. The analysis shows that the Santiaguito dome complex grew by $0.78 \pm 0.07 \mathrm{~km}^{3}\left(0.52 \pm 0.05 \mathrm{~m}^{3} \mathrm{~s}^{-1}\right)$ over the 1954-2001 period with nearly all the growth occurring on the El Brujo (1958-75) and Caliente domes (1971-2001). Adding information from field data prior to 1954, the total volume extruded from Santiaguito since 1922 is estimated at $1.48 \pm 0.19 \mathrm{~km}^{3}$. Santiaguito's growth rate is lower than most other volcanic domes, but it has been sustained over a much longer period and has undergone a change toward more exogenous and progressively slower extrusion with time. At Santiaguito some of the material being added at the dome is subsequently transported downstream by block and ash flows, mudflows and floods, creating channel shifting and areas of aggradation and erosion. At Pacaya volcano a total volume of $0.21 \pm 0.05 \mathrm{~km}^{3}$ was erupted between 1961 and 2001 for an average extrusion rate of $0.17 \pm 0.04 \mathrm{~m}^{3} \mathrm{~s}^{-1}$. Both the Santiaguito and Pacaya eruption rate estimates reported here are minima, because they do not include estimates of materials which are transported downslope after eruption and data on ashfall which may result in significant volumes of material spread over broad areas. Regular analysis of high resolution DEMs using the methods outlined here, would help quantify the effects of 
fluvial changes to downstream populated areas, as well as assist in tracking hazards related to dome collapse and eruption. 


\section{Introduction}

The Central American Volcanic Front crosses Guatemala from Mexico to El Salvador, and consists of a linear belt of stratovolcanoes, silicic domes, and calderas, over an area of actively changing topography (Vallance et al. 1995; Carr et al. 2007). The volcanoes give rise to volcanogenic sediment accumulating downslope of the growing volcanic chain, affecting many rivers, which cross the heavily populated coastal slope (Vessell and Davies, 1981). Uplift of the entire region is likely from subduction of the Cocos Plate under the Chortis terrain (Rogers et al. 2002), which is marked by slivered transcurrent faults (DeMets, 2001).

Santiaguito is located on the SW flank of Santa María stratovolcano (3772 m) in SW Guatemala and is 10 km away from Quetzaltenango, Guatemala’s second largest city (Figure 1.1).

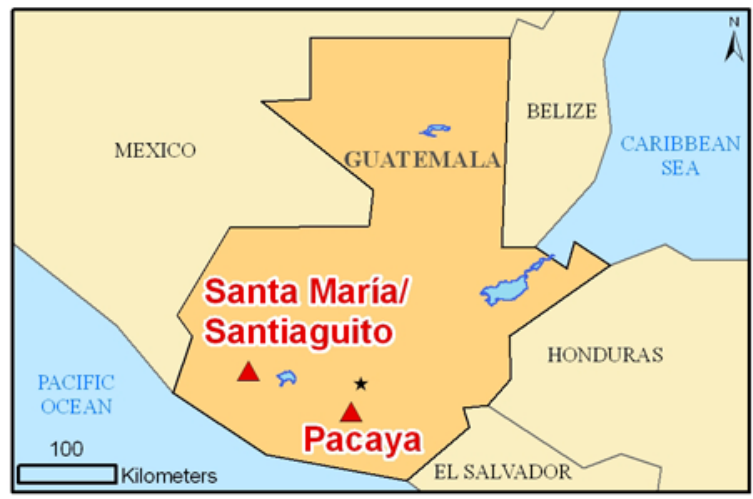

Figure 1.1 Map of Guatemala with Santa María/Santiaguito and Pacaya Volcanoes. Guatemala City, the capital, is denoted by the black star. Map created by author with data found in ESRI ArcGlobe.

Santiaguito has grown from continuous extrusion of dacite since 1922 (Sapper, 1926;

Rose 1987; Harris et al. 2004) following a plinian eruption in 1902 from Santa María (Sapper, 1903; Williams and Self, 1983), building a complex of dacitic domes and 
blocky lava flows (Rose 1972a, 1987; Harris et al. 2003, 2004). Between 1922 and 1984 Santiaguito grew in a series of 3-5 year bursts of high extrusion $\left(0.6-2.1 \mathrm{~m}^{3} \mathrm{~s}^{-1}\right)$ and 1012 year intervals of lower extrusion $\left(\sim 0.2 \mathrm{~m}^{3} \mathrm{~s}^{-1}\right)$ (Rose 1973, 1987). At Santiaguito much of the volcanic material erupted is transported downstream due to block and ash flows and lahars, which may be deposited as far away as the ocean due to further fluvial transport (Kuenzi et al. 1979; Harris et al. 2006). In November 1929, dome collapse led to a block and ash flow which flowed $~ 10$ kilometers from the volcano devastating several populated areas and resulting in hundreds of deaths (Sapper and Termer, 1930; Simkin and Siebert, 1994). Block and ash flows have occurred almost every year at Santiaguito and consequent lahar hazards are prevalent in the rainy season when heavy rains remobilize block and ash flow materials and carry them downstream, producing lahars, hyperconcentrated flows, and flood deposits. This activity aggrades the parallel rivers of the alluvial fan and presents a serious and very complex hazard for the communities surrounding the dome complex and the rivers that drain it (Harris et al. 2006). Changes in topography of volcanic domes are fundamental for the understanding of consequent hazards from dome collapses (Swanson et al 1987; Miller, 1994).

Pacaya volcano is located $\sim 28 \mathrm{~km} \mathrm{~S}$ of Guatemala City and lies on the S edge of Amatitlán caldera (Wunderman and Rose, 1984). Pacaya’s activity is episodic with eruptive intervals of 50-300 years during which lava and scoria are erupted, and longer dormant intervals lasting between 300-500 yr (Conway, 1992). Activity at Pacaya can be subdivided into three stages: initial, historical, and recent (Eggers, 1971). The initial phase consisted of cone construction by large flows and tephra deposits (Kitamura and Matías, 1995). Strombolian activity continued between 2000 and 400 yr BP, until a 
large sector collapse occurred creating a debris avalanche of $0.6 \mathrm{~km}^{3}$ and a prominent arcuate scar (Vallance et al. 1995). The historic stage continued, consisting of Strombolian periodic cone building eruptions, occurring periodically since 1565 (GVN, 2008). Pacaya was in repose from 1885-1961 when an eruption occurred without warning in March of 1961 (Conway, 1992); beginning the current eruption phase. After a lava flow eruption in 1961 and four years of repose, Pacaya has been continuously active with Strombolian eruptions causing tephra fall, ballistic bombs, and lava flows (Eggers, 1971; 1983), which built a new cone (Mackenney Cone) on the west side of the older (1775-1885) cone. The possibility of debris avalanches or volcanic edifice sector collapses are a concerning hazard for the future at Pacaya, especially in view of its dramatic record of its catastrophic collapse in the past (Vallance et al. 1995).

Topographic changes have been studied at many volcanoes using Radar (Rowland et al. 1999), GPS (Wadge et al. 2006), and DEMs (Stevens et al. 1997; Baldi, 2002; Kerle, 2002). Ideally a topographic study is conducted using very high resolution data acquired from Radar, InSAR, GPS, etc. Many regions of the world do not have highly accurate elevation data, and other methods need to be used, such as deriving DEMs from topographic maps. These DEMs can be extremely helpful in areas where very little elevation data exists, which is the case in Guatemala. The Santiaguito dome complex and Pacaya volcano are excellent study areas for evaluating DEM-based extrusion rate estimates as a result of their continuous activity, which has produced significant topographic changes near the active vents. The topography is steep and irregular and is changing continually from both erosion and addition of new volcanic material. In this paper we quantify the rate of topographic change at Santiaguito and 
Pacaya volcanoes over the past $\sim 50$ years using high resolution digital elevation models (DEMs) obtained from aerial photographs and topographic maps. 


\section{Methods}

\subsection{DEM differencing}

In the 1950’s basic topographic mapping of Guatemala was completed by the Instituto Geográfico Nacional (IGN) and country-wide 1:50,000 quadrangle maps were compiled. These maps are still widely used and are essential for hazards evaluation because they describe the complex topography of the volcanic front. Quadrangle maps, based on aerial photography from January- March 1954, for Santiaguito and Pacaya (IGN, Guatemala, sheets Colombá (1860 II), Retalhuleu (1859 I), San Lorenzo (1859 II), and Amatitlán (2059 II)) had 20 m contour lines, which were digitized from clear film and exported to an ArcINFO export format (.e00) (USGS, 2001). The United States

Geological Survey (USGS) used these 20 m elevation contours to produce $10 \mathrm{~m}$ pixel DEMs (pers. comm. Steve Schilling, 2007).

In February 2001 the Japan International Cooperation Agency (JICA) in cooperation with various Guatemalan agencies, generated new digital topography of some key hazard areas, including Santiaguito and Pacaya, from aerial photographs (JICA, 2003). We used the 2001 digital contour lines from JICA to interpolate $10 \mathrm{~m}$ DEMs using the ANUDEM algorithm developed by Hutchinson (1993). The 2001 DEMs were converted to the UTM Zone 15 NAD 1927 coordinate system and datum to align with the 1954 DEMs. In this study we use DEM data created from the 1950’s topographic maps and the 2001 JICA digital topography as primary data sources to examine topographic changes at Santiaguito and Pacaya and the areas surrounding them. 
Volume and elevation change was estimated in this study by subtracting the 1954 DEMs from the 2001 DEMs (See Appendix I for DEM differencing steps).

Field observations and existing maps were used to outline active volcanic areas at Santiaguito and Pacaya, resulting in analysis masks. Analysis masks were used to clip or cut out certain areas of interest allowing the user to process only the features within the mask. Analysis masks were created for Santiaguito at (1) the El Brujo Dome region, active from 1958-75 (Rose, 1972a, 1987), for (2) the Caliente Dome region, active from 1971 to present and for (3) a region on the south flank of the La Mitad and El Monje Domes, which was subject to severe erosion during 1954-2001. In all of the masked regions we subtracted the 1954 DEM from the 2001 DEM, giving us a difference DEM for each region. At Pacaya, the complexity of volume change was much less that that of Santiaguito and a single active mask was analyzed.

\subsection{DEM error estimation}

Errors within the DEM may be caused by random errors, systematic errors during data collection, interpolation errors, and regional uplift in the region. We first estimate the error of interpolation using the root mean square error as shown below:

$$
\text { RMSE }=\sum_{i=1}^{n} \sqrt{\frac{\left(Y_{i}-y_{i}\right)}{n}}
$$

Where $n$ is the number of reference points, $y_{i}$ is the elevation at reference point $i$, and $Y_{i}$ is the elevation from the DEM at point $i$. Interpolation of contour lines to create a DEM results in some error; therefore the RMS error was used to measure this effect. The 1954 data had no independent set of control points; therefore the contour lines, which were used to interpolate the DEM, were converted to points, and a random sample of 500 
points were taken out of $\sim 500,000$. The sample points were then compared to the DEM and a vertical RMSE was obtained. This error represents the error introduced from the interpolation process which was conducted by the USGS (2001). The 2001 data included elevation points at a spacing of $40 \mathrm{~m}$, which were interpolated from the original orthophotographs (JICA, 2003). The 40 m points were not used to create the DEM, so they represent a separate reference point which was used to calculate the RMSE. A random sample of 500 was taken, out of a possible $\sim 1$ million, and those points were compared to the DEM yielding a vertical RMSE. Independent ground control points (GCP's) were not created for this study; therefore the existing elevation data was used to estimate the interpolation error. Errors due to re-projection are considered insignificant with very little distortion taking place due to the small area studied (Steinwand et al. 1995).

In addition to the interpolation, there are systematic errors within the dataset due to errors in data collection (i.e. manual drawing of contour lines, digitization etc.). Systematic errors are hard to measure and ideally the original aerial stereographic data should be used, but these were not available for this study. A study done by Shearer (1990), estimated the error resulting from digitization of the contours to be $\pm 0.25 \mathrm{~m}$. This estimate has been used in other lava volume studies (Stevens et al. 1997; Stevens et al. 1999), and is believed to be suitable for this study. Other error sources (tree cover, uplift etc.) are believed to be negligible and are discussed later in more detail. 


\section{Results}

\subsection{Estimated Errors}

The RMSE due to interpolation is $2.2 \mathrm{~m}$ and $5.7 \mathrm{~m}$ for the 1954 and 2001 DEMs respectively. The 1954 and 2001 DEMs were mosaiced from three DEMs, for Santaiguito. All three DEMs are believed to have the same error since the aerial photographs were obtained at the same time, therefore the RMSE due to interpolation was determined once for the 1954 and 2001 DEMs. The Pacaya DEMs are believed to have the same error since they were created at the same time as the Santiaguito DEMs. The error estimated from digitization of contours was estimated as $0.25 \mathrm{~m}$, as defined by Shearer (1990). The above errors were added resulting in an overall DEM error of 8.15 m (Table 3-1) and was used to calculate the volume errors by multiplying the volcanic area by the DEM error.

Table 3-1 Table showing RMSE for each DEM due to interpolation, as well as the digitization error. The Total DEM Error was found to be $8.15 \mathrm{~m}$.

\begin{tabular}{|c|c|c|c|}
\hline 1954 RMSE (m) & 2001 RMSE (m) & $\begin{array}{c}\text { Digitization } \\
\text { Error (m) }\end{array}$ & $\begin{array}{c}\text { Total DEM } \\
\text { Error (m) }\end{array}$ \\
\hline 2.2 & 5.7 & 0.25 & $\mathbf{8 . 1 5}$ \\
\hline
\end{tabular}

\subsection{Santiaguito Dome}

Based on DEM differencing for 2001 and 1954, elevation changes occurred inside and outside of the dome as shown in Figures 3.1a and 3.2 respectively. Figure 3.2 has elevation changes occurring outside of the active dome, with much of the image showing small elevation change. The large elevation loss ( $>-50 \mathrm{~m})$ in the Santa María crater wall represents an area of rapid erosion due to very steep slopes $\left(>45^{\circ}\right)$. The amount of erosion from this is estimated at $0.05 \pm 0.02 \mathrm{~km}^{3}$, with a maximum elevation 
loss of $150 \mathrm{~m}$. This erosion contributes to the volume of material accumulating within the 1902 crater region to the south, which is masked as part of the active dome. We assume the eroded material from Santa María contributes very little to the overall dome volume and did not attempt to determine how much of this material was deposited outside of the masked dome region. In addition to the wall of Santa María, there are other regions which show large (+50 m) elevation changes outside of the dome itself. Because they are found at high elevations within this area of frequent fog, we suggest that these possibly reflect poor visibility regions (cloud or mist) on either of the aerial photographs used for contouring which resulted in misalignments. In addition, the large elevation changes may be caused by misalignment of contours from data collection and interpolation methods. Comparison of the dome region and areas outside reveal the mean elevation change is very different (Table 3-2). The means (both algebraic and absolute) are significantly higher in the dome region, than that outside; indicating much larger elevation change is occurring in the dome region.

Table 3-2 Table showing mean elevation change for the dome and the region outside. The algebraic mean and standard deviation are shown for elevation change, as well as the absolute mean and standard deviation values. Note the difference between the mean changes, with much higher elevation change occurring in the dome region.

\begin{tabular}{|c|c|c|c|c|}
\hline Region & $\begin{array}{c}\text { Mean Elev. } \\
\text { Change (m) }\end{array}$ & $\begin{array}{c}\text { Standard Dev. } \\
\text { Elev. Change (m) }\end{array}$ & $\begin{array}{c}\text { Abs. Mean Elev. } \\
\text { Change (m) }\end{array}$ & $\begin{array}{c}\text { Abs. Stand. Dev. } \\
\text { Elev. Change (m) }\end{array}$ \\
\hline Dome & 92.70 & 78.96 & 100 & 68.5 \\
\hline $\begin{array}{c}\text { Outside } \\
\text { Dome }\end{array}$ & 8.05 & 26.12 & 17.2 & 21.2 \\
\hline
\end{tabular}



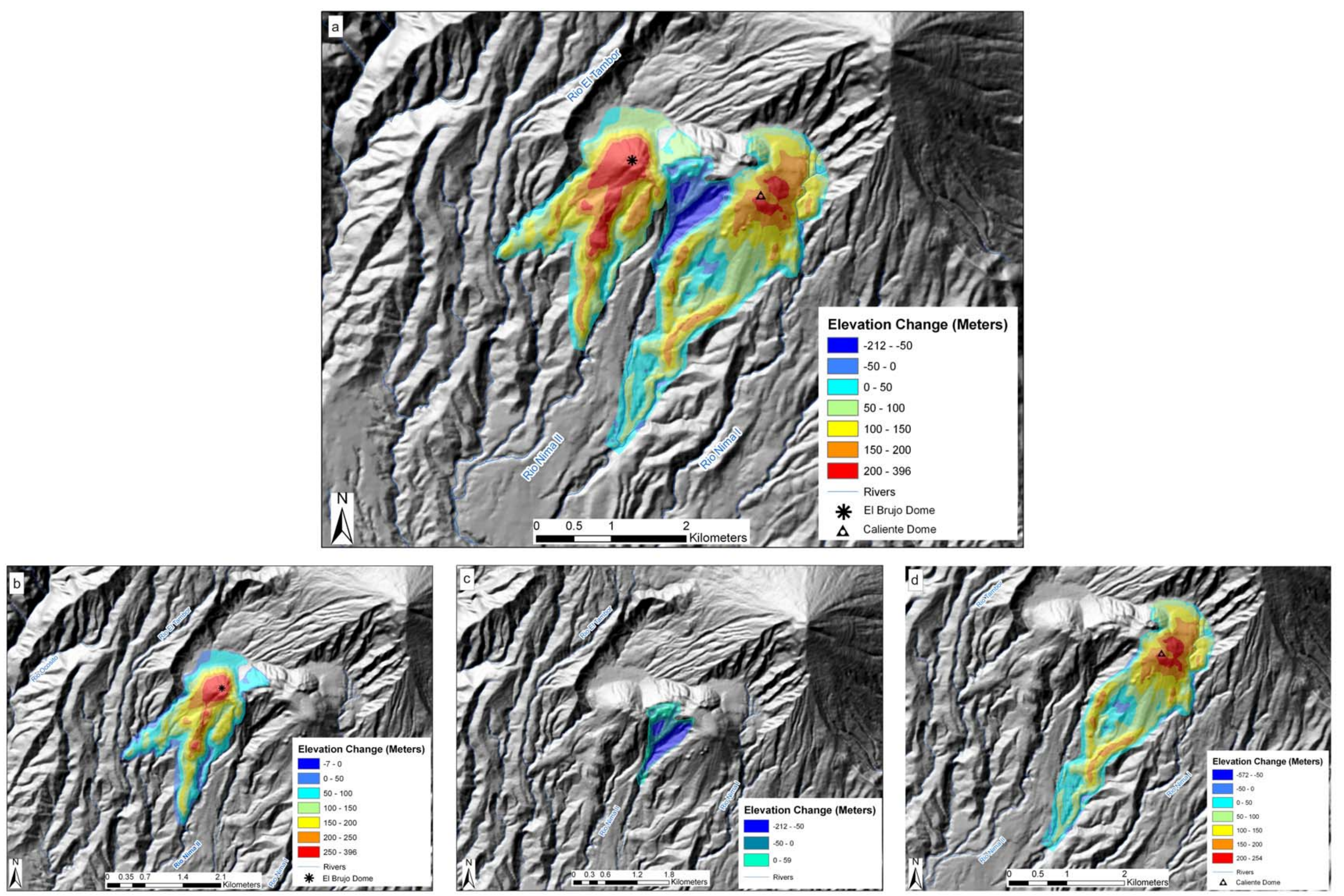

Figure 3.1 Elevation change map for the Santiaguito dome with a volume change of $0.78 \pm 0.07 \mathrm{~km}^{3}$. b. Elevation change at El Brujo with a volume change of $0.42 \pm 0.03 \mathrm{~km}^{3}$. c. An area of large elevation loss is shown between b and d, with a lume loss of $0.03 \pm 0.01 \mathrm{~km}^{3}$. d. Elevation change at Caliente with a volume change of $0.39 \pm 0.03 . \mathrm{km}^{3}$. 


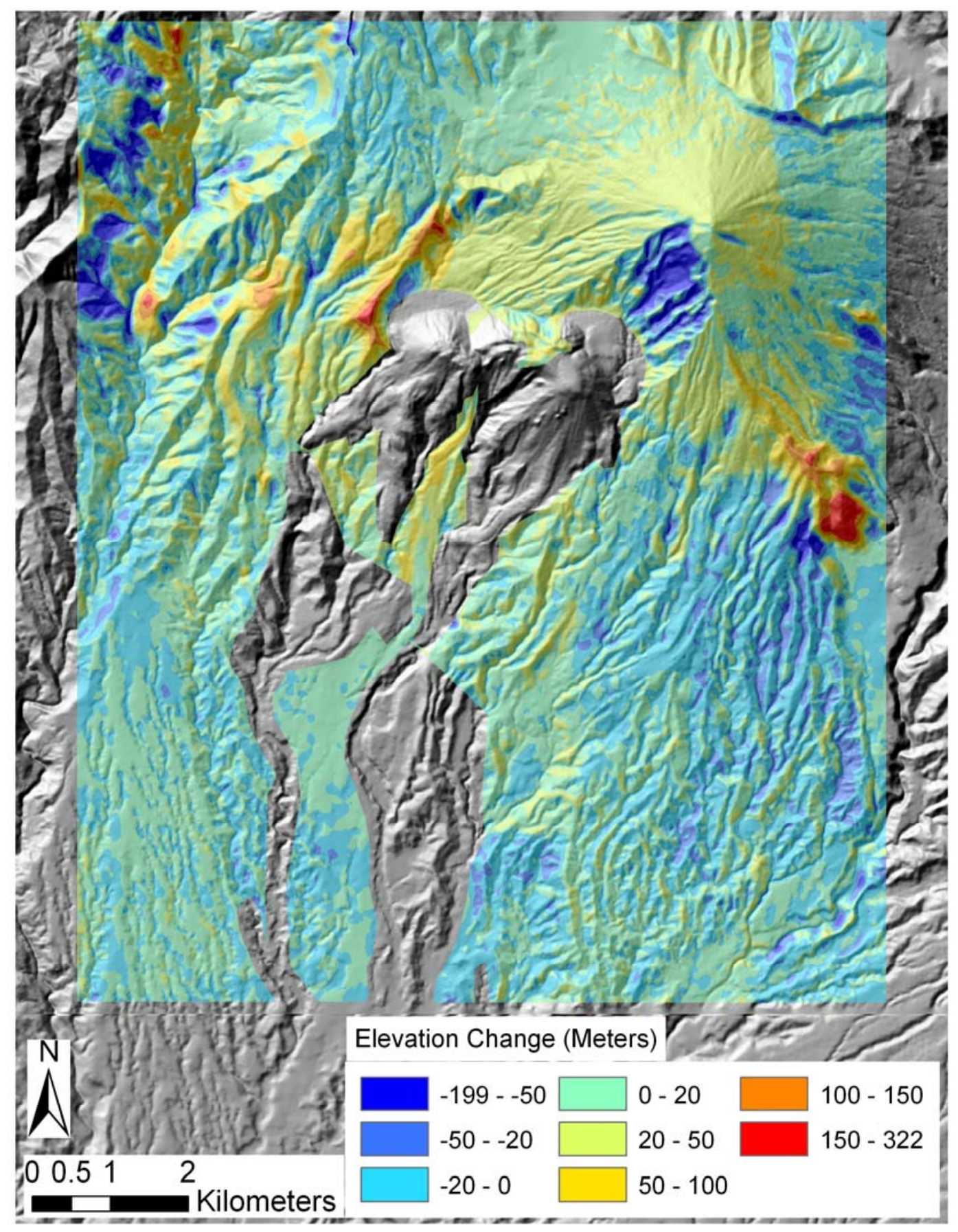

Figure 3.2 Elevation change map outside of the dome. 
The dome region comprises two areas of positive elevation change (> $150 \mathrm{~m}$ ), which coincide with the El Brujo (1958-1975) and Caliente (1971-present) domes (Rose 1972a; 1987). In addition, a region of negative topographic change ( $<-50 \mathrm{~m})$ is depicted between the two active dome regions, which is a rapidly eroded region during the test period (1954 to 2001). A volume change of $0.42 \pm 0.03 \mathrm{~km}^{3}$ and $0.39 \pm 0.03 \mathrm{~km}^{3}$ was estimated for the El Brujo and Caliente domes respectively (Figure $3.1 \mathrm{~b}$ and d). The highly eroded region between El Brujo and Caliente resulted in a volume loss of $0.03 \pm$ $0.01 \mathrm{~km}^{3}$ (Figure 3.1c). The mean extrusion rate for El Brujo, $0.78 \pm 0.04 \mathrm{~m}^{3} \mathrm{~s}^{-1}$, was calculated from 1954-1975 during the active period, while the mean extrusion rate for Caliente, $0.41 \pm 0.03 \mathrm{~m}^{3} \mathrm{~s}^{-1}$, was calculated from 1971-2001 (the end of the study period). The overall volume change for the dome region (excluding the lost volume from Santa María) is $0.78 \pm 0.07 \mathrm{~km}^{3}$ yielding an average extrusion rate of $0.52 \pm 0.05$ $\mathrm{m}^{3} \mathrm{~s}^{-1}$ from 1954 to 2001 (Figure 3.1a, Table 3-3). The volume error was calculated by multiplying the DEM error and the volume error as shown in Table 3-3.

Table 3-3 Summary table for DEM error, Area, and Volume Change. Volume changes for each region with error estimates are shown.

\begin{tabular}{|c|c|c|c|c|}
\hline Region & $\begin{array}{c}\text { DEM Error } \\
\mathbf{( m )}\end{array}$ & $\begin{array}{c}\text { Area } \\
\left.\mathbf{( k m}^{\mathbf{2}}\right)\end{array}$ & $\begin{array}{c}\text { Volume Error } \\
\mathbf{( k m}^{\mathbf{3}} \mathbf{)}\end{array}$ & $\begin{array}{c}\text { Volume Change } \\
\mathbf{( k m}^{\mathbf{3}} \mathbf{)}\end{array}$ \\
Dome & 8.15 & 8.4 & 0.07 & $0.78 \pm 0.07$ \\
Pacaya & 8.15 & 6.8 & 0.05 & $0.21 \pm 0.05$ \\
\hline
\end{tabular}

In addition to changes occurring at the dome, flows from the Caliente dome are impacting Río Nimá I and II with addition of material in the river channels (Harris et al. 2006), which can be seen in the dome region (Figure 3.1 a). Areas downstream of Santiaguito were analyzed for elevation change, but the volume changes shown in these 
regions were small compared to computed errors, so we do not attempt to estimate here how much erupted materials are carried downslope by pyroclastic flows, mudflows, and floods. We do know that all of these downslope depositional events are occurring every year at Santiaguito (Harris et al. 2006).

\subsection{Pacaya}

Based on DEM differencing for 2001 and 1954, elevation changes occurred inside and outside of the Pacaya region as shown in Figures 3.5 and 3.6. Figure 3.6 measures elevation changes occurring outside of the Pacaya region, with much of the image showing small elevation change. Pacaya had a volume change of $0.21 \pm 0.05 \mathrm{~km}^{3}$ with an average eruption rate of $0.17 \pm 0.04 \mathrm{~m}^{3} \mathrm{~s}^{-1}$ for a masked area of $1 \times 10^{6} \mathrm{~m}^{2}$ (Figure 3.5, Table 3-3). The average eruption rate of $0.17 \pm 0.04 \mathrm{~m}^{3} \mathrm{~s}^{-1}$ was determined from 1961-2001, as Pacaya was not active from 1954-1961. Pacaya began the current eruption phase in 1961 creating a lava flow with deposition ranging from 10-50 meters and continued with lava flows and spatter deposits from 1965-2001 which are present in the north. The volume changes shown do not quantify tephra falls that caused deposition outside of the test region. These were numerous but mostly small in volume, although the Jan. 16, 2000 fall deposit certainly resulted in significant additional volume (BGVN, 1999). Comparison of the Pacaya region and areas outside reveal the mean elevation change is very different (Table 3-4). The means (both algebraic and absolute) are significantly higher in the Pacaya region, than that outside, indicating much larger elevation change is occurring in the volcanic region. 
Table 3-4 Table showing overall DEM error. The algebraic mean and standard deviation are shown for elevation change, as well as the absolute mean and standard deviation values. Note the difference between the mean changes, with much higher elevation change occurring in the volcanic region.

\begin{tabular}{|c|c|c|c|c|}
\hline Region & $\begin{array}{c}\text { Mean Elev. } \\
\text { Change (m) }\end{array}$ & $\begin{array}{c}\text { Stand. Dev. Elev. } \\
\text { Change (m) }\end{array}$ & $\begin{array}{c}\text { Abs. Mean Elev. } \\
\text { Change (m) }\end{array}$ & $\begin{array}{c}\text { Abs. Stand. Dev. } \\
\text { Elev. Change (m) }\end{array}$ \\
\hline Pacaya & 31.36 & 43.97 & 34.9 & 41.2 \\
\hline Outside & -3.54 & 10.61 & 8.8 & 6.8 \\
\hline
\end{tabular}




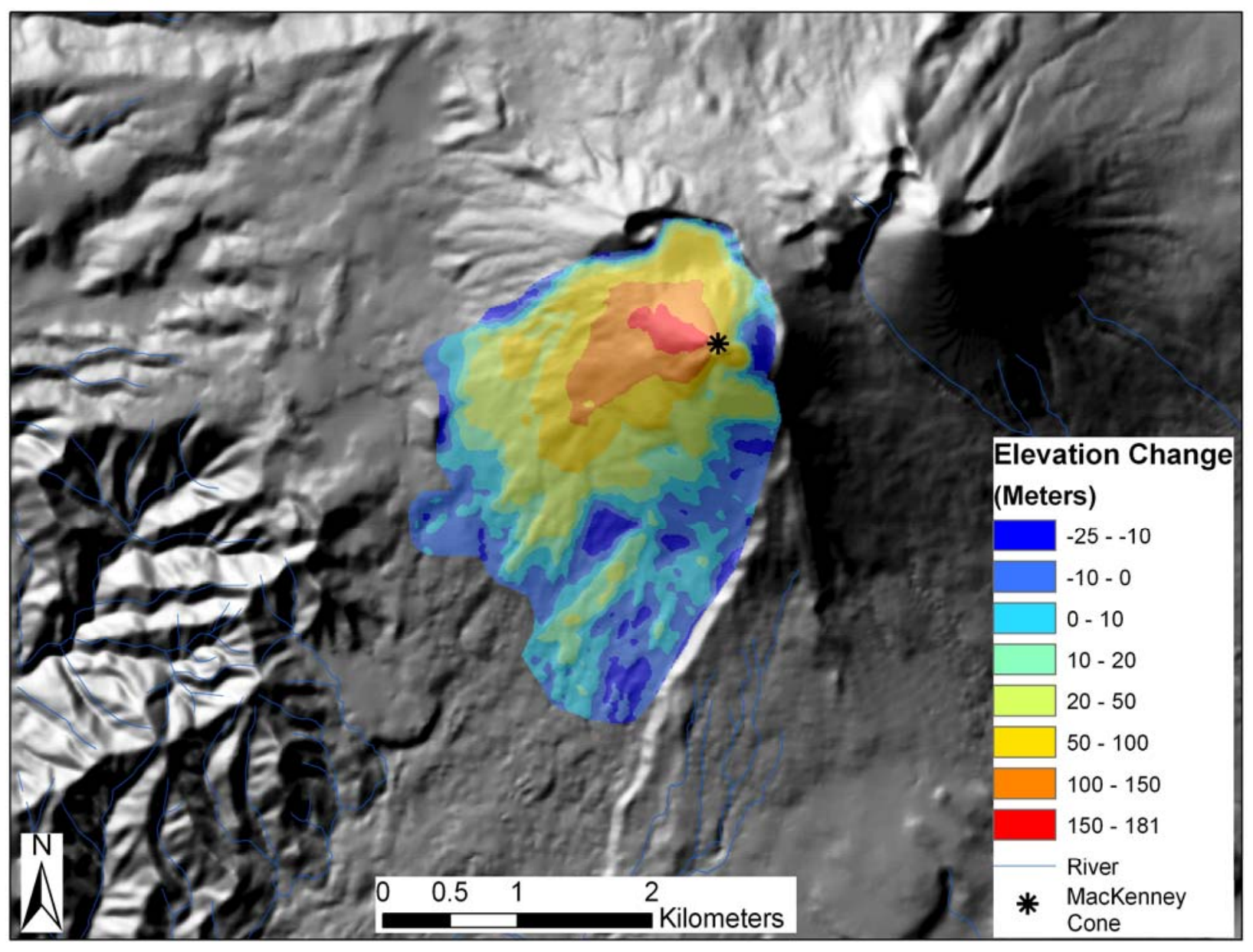

Figure 3.3 Elevation change map of Pacaya volcano with a volume change of $0.21 \pm 0.05 \mathbf{k m}^{3}$. 


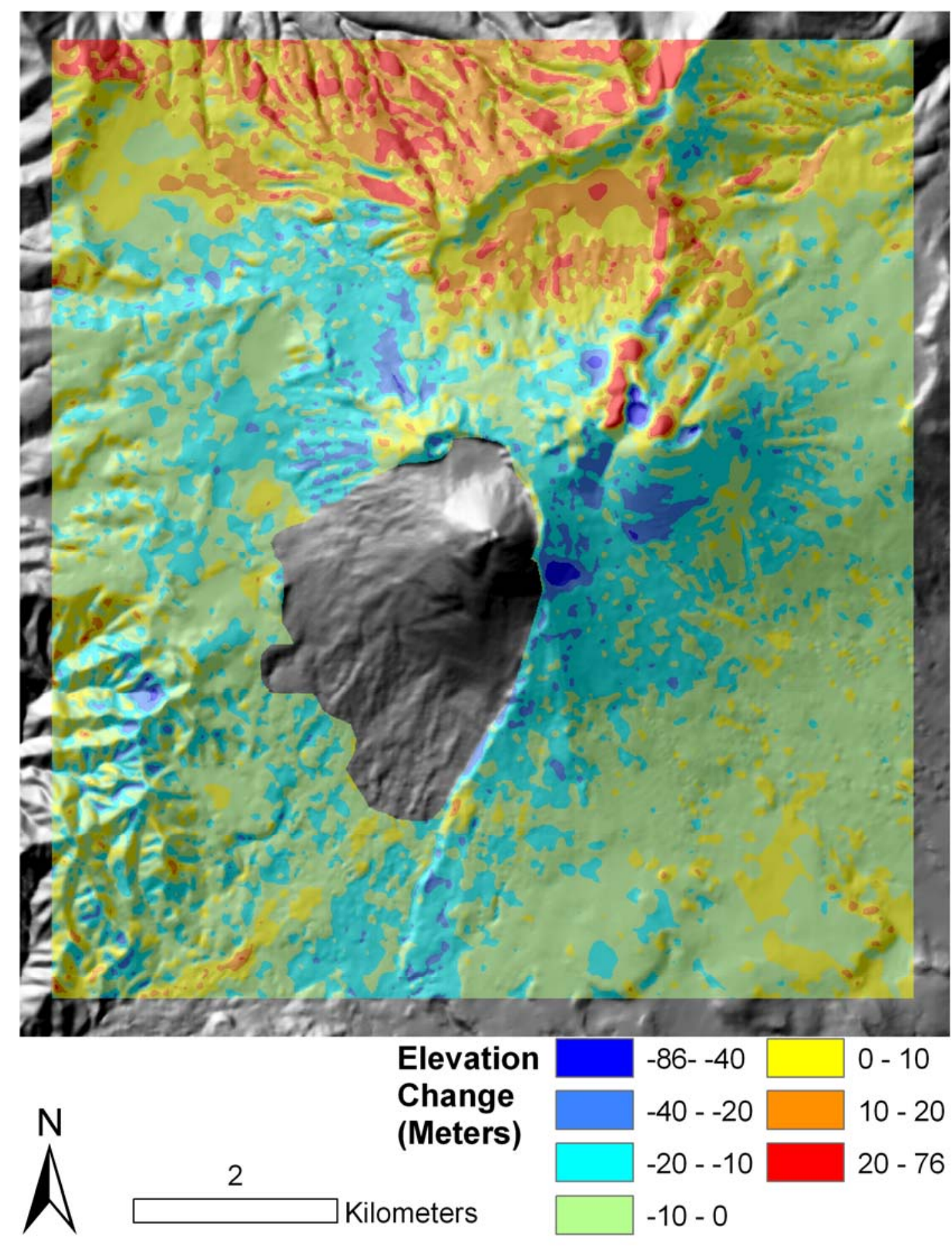

Figure 3.4 Elevation change map outside of the Pacaya region 


\section{Discussion}

\subsection{Santiaguito Volume Changes}

El Brujo was active from 1958-1975 and during that time erupted six blocky lava flows as described by Rose (1987) and Harris et al. (2003). Figure 4.1 outlines some of these flows from a new geologic map of Santiaguito (Escobar et al. 2008). Many of the large flows along the west side of Santiaguito occurred from 1958-1974 and coincide with the volume changes we found in the El Brujo vent region.

The analysis of Caliente dome, active from 1971 to present, reveals that volume change patterns mapped here coincide with the emplacement of many lava flows, including units emplaced from 1972 until 2006 (Figure 4.1, Escobar et al. 2008). Two areas of high elevation change ( $>200 \mathrm{~m})$ are shown to the north and south of the Caliente vent (Figure 3.2d). This pattern was created from lava flow material accumulating near the Caliente vent first, with lava flows from 1972-73 flowing north of the vent into the 1902 crater, and later lava flows occurring in the early 90's causing thickening south of the vent (Harris et al. 2003). An area of erosion (loss of 0-200 m) has developed between the Caliente and El Brujo vents and occurs at a steep area on the flank, where rocksliding and fluvial erosional energy is concentrated. 


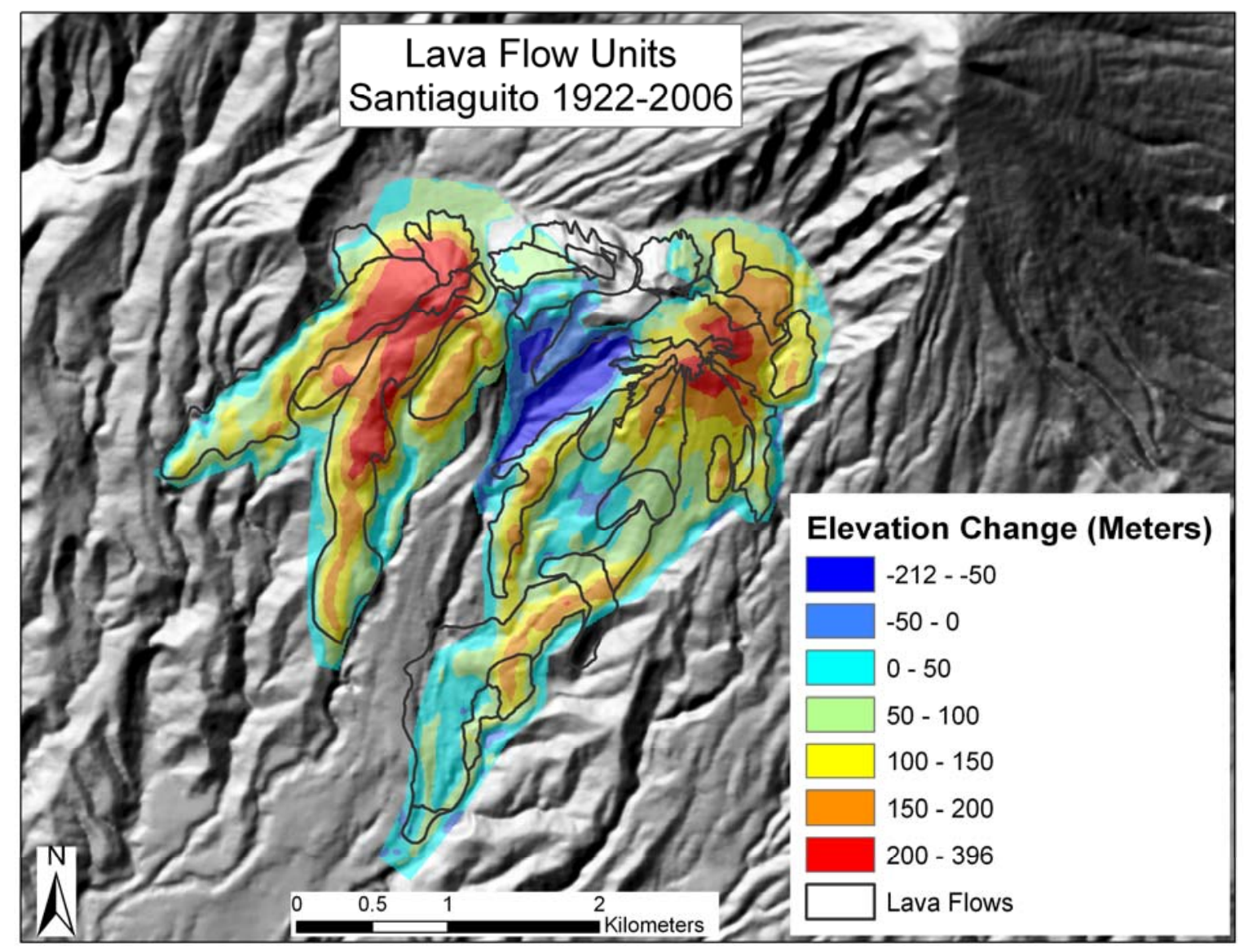

Figure 4.1 Elevation change map for Santiaguito with lava flows units shown in black as defined by Escobar et al. (2008) from 1922-2006. Much of the elevation change relates directly to the lava flow emplacement, but the use of this map, especially around the Caliente vent misleads by emphasizing recent units that may in many cases cover up units previously extruded. 
Comparison with previous work

The volume change at the dome between 1954 and 2001 is $0.78 \pm 0.07 \mathrm{~km}^{3}(0.52$ $\pm 0.05 \mathrm{~m}^{3} \mathrm{~s}^{-1}$ ), with much of the deposition occurring at El Brujo and Caliente. Adding the field based estimates from 1922-1954 of $0.7 \mathrm{~km}^{3}$ (Rose et al. 1970; Rose 1972b, 1987), gives a total volume change from $1922-2001$ of $1.48 \pm 0.20 \mathrm{~km}^{3}$ (Table $4-1$ ). Volume estimates for units emplaced prior to 1986 were not based on topography derived from photogrammetry and had estimated errors of $\pm 25 \%$ of the volume (Harris et al. 2003).

Table 4-1 Volume calculations for 1922-2001. The volume estimates are also shown from 1922-1954 based on previous field estimates with a $25 \%$ error estimate. The 1922-2001 volume change for Santiaguito is $1.48 \pm \mathbf{0 . 1 9}$.

\begin{tabular}{|c|c|c|c|}
\hline Region & $\begin{array}{c}1954-2001 \\
\text { Volume }\left(\mathrm{km}^{3}\right)\end{array}$ & $\begin{array}{c}1922-1954 \\
\text { Volume }^{a}\left(\mathrm{~km}^{3}\right)\end{array}$ & $\begin{array}{c}1922-2001 \\
\text { Volume }\left(\mathrm{km}^{3}\right)\end{array}$ \\
\hline Dome & & \multirow{5}{*}{0.7} & \\
\hline El Brujo & 0.42 & & \\
\hline Caliente & 0.39 & & \\
\hline La Mitad Erosion & -0.03 & & \\
\hline Santa María Erosion & $-0.05^{*}$ & & \\
\hline Dome Total & $0.78 \pm 0.07$ & $0.7 \pm 0.18$ & $1.48 \pm 0.19$ \\
\hline
\end{tabular}

* Santa María erosion is not included in the dome total since we are unsure how much of this erosion is within the dome region. We believe this volume is contributing very little to the overall dome volume.

${ }^{a}$ Rose et al. 1970; Rose 1972b, 1987

The volume changes quantified here for Santiaguito (Table 4-1) do not include the additional volumes of airfall ash deposited outside of the masked areas associated with weak hourly vertical explosions and far less frequent block and ash flows. The erosion occurring on the steep walls of Santa María are not included in the overall volume, because this erosion is believed to be contributing very little to the volume erupted at the dome. We do not attempt to quantify the volume of this material, but instead acknowledge that our estimate here is a minimum volume change. In addition, the 
proximal and medial regions, which were found to be insignificant in this study and are not included here, are believed to be contributing to the overall Santiaguito volume due to downslope sedimentation which has been previously documented (Kuenzi et al. 1979; Kimberly, 1995; Harris et al. 2006).

Previous estimates of volume change from 1922-2000 were found to be $1.3 \mathrm{~km}^{3}$ (Rose et al. 1970; Rose 1972b, 1987; Harris et al. 2003). Our results are thus in good agreement with the previous estimate $\left(1.3 \mathrm{~km}^{3}\right)$, but have improved errors $(1.48 \pm 0.19$ $\mathrm{km}^{3}$ ).

\subsection{Comparison with other domes}

From 1954-2001 the effusive activity at Santiaguito has been mainly exogenous and consists of a cyclical pattern of low and high extrusion rates (Harris et al. 2003). Similar pulsating behavior has been observed at other active domes e.g. the 1980-83 eruptive period of Mount. St. Helens (Swanson et al.1987). Table 4-2 shows the main parameters of growth for six domes compared to Santiaguito. 
Table 4-2 Volume and extrusion rates for various volcanic domes

\begin{tabular}{|c|c|c|c|c|c|c|c|}
\hline & Santiaguito $^{\mathrm{a}}$ & $\begin{array}{l}\text { Mount St. } \\
\text { Helens* b,c }\end{array}$ & Augustine $^{\mathrm{d}}$ & Montserrat $^{\mathrm{e}}$ & $\underset{f \text { f,g }}{\text { Unzen }}$ & $\underset{\mathrm{h}}{\text { Redoubt }}$ & $\underset{i,, j}{\text { Merapi }}$ \\
\hline \multicolumn{8}{|c|}{ Period of dome growth } \\
\hline From & Jan-54 & $\begin{array}{c}\text { Oct-80/ Oct- } \\
04\end{array}$ & Jan-06 & Nov-95 & Oct-91 & Dec-89 & 1890 \\
\hline To & Feb-01 & $\begin{array}{l}\text { Dec-83/ } \\
\text { Dec-05 }\end{array}$ & Mar-06 & Mar-98 & Mar-93 & June-90 & Jan-92 \\
\hline $\begin{array}{l}\text { Duration } \\
\text { (yr) }\end{array}$ & 47 & $3.2 / 1.2$ & 0.25 & 2.3 & 1.4 & 0.5 & 102 \\
\hline $\begin{array}{l}\text { Dome } \\
\text { Volume } \\
\left(\mathrm{km}^{3}\right)\end{array}$ & 0.78 & $0.04 / 0.07$ & 0.018 & 0.3 & 0.09 & 0.09 & 0.10 \\
\hline $\begin{array}{l}\text { Average } \\
\text { eruption } \\
\text { rate }\left(\mathrm{m}^{3}\right. \\
\left.\mathrm{s}^{-1}\right)\end{array}$ & $\sim 0.52$ & $\begin{array}{c}\sim 0.41 / \\
\sim 1.93\end{array}$ & 2.7 & $\sim 4.1$ & $\sim 2.0$ & 5.92 & 0.04 \\
\hline $\begin{array}{l}\mathrm{SiO}_{2} \\
\text { Content }\end{array}$ & $63-68 \%$ & $61-64 \%$ & $56-64 \%$ & $58-62 \%$ & $64-66 \%$ & $58-63 \%$ & $\begin{array}{c}53- \\
55 \%\end{array}$ \\
\hline
\end{tabular}

Figure 4.2 shows the relationships between lava volume, duration and eruption rate for these documented cases. Larger domes tend to extrude for longer periods at slower extrusion rates. Merapi has a much lower eruption rate but has been erupting for well over 100 years. Merapi and Santiaguito have similar eruption cycles dominated by high extrusion for shorter periods and lower extrusion rates for longer periods (Siswowidjoyo et al. 1995; Voight et al 2000). 


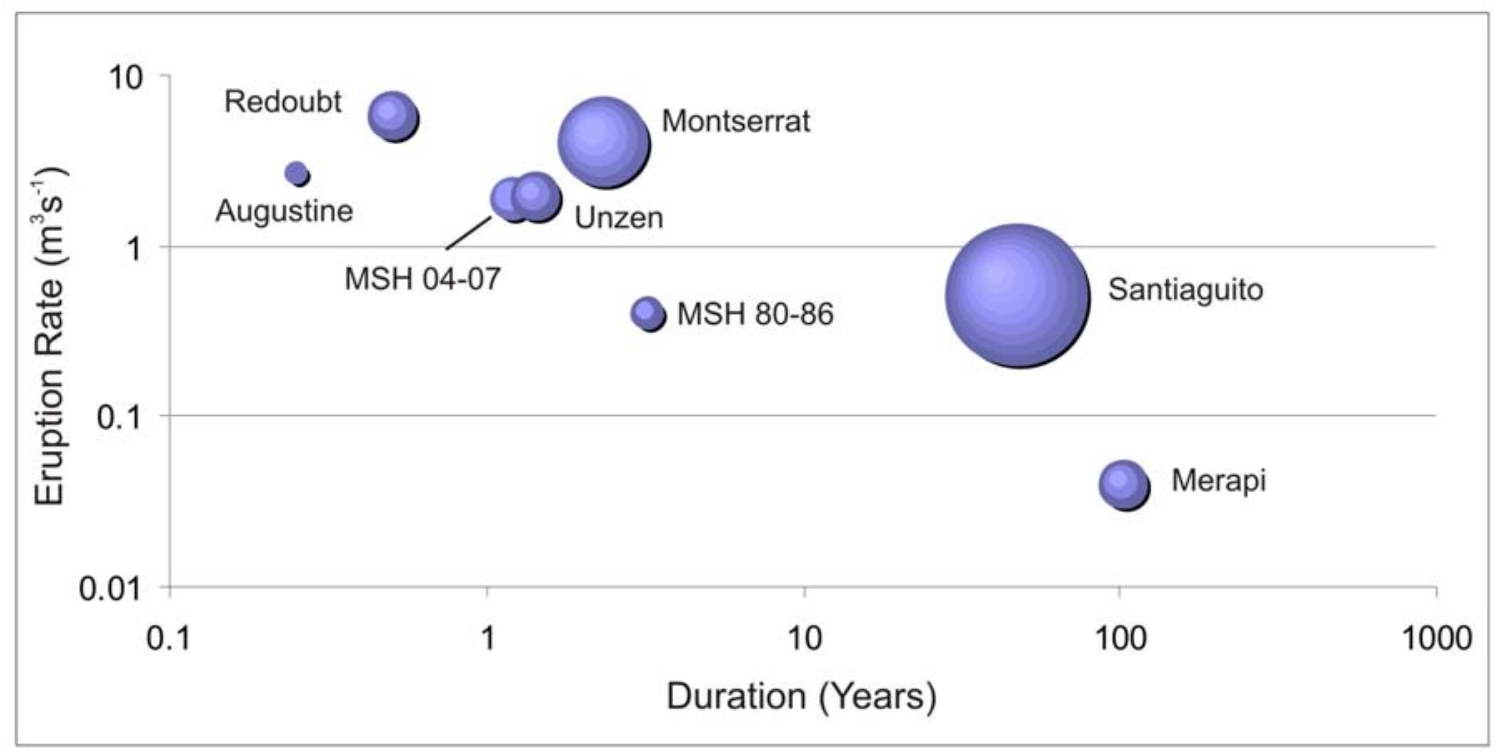

Figure 4.2 Graph showing duration in years vs. eruption rate. The areas of circles plotted are proportional to overall lava volume.

Both Montserrat (1995-1998) and Redoubt (1989-1990) created many domes which were emplaced and destroyed through endogenous and exogenous growth (Miller, 1994; Watts et al. 2002). In 2006, Augustine showed similar characteristics with the formation of a new lava dome resulting in failure, causing block and ash flows (Power et al. 2006). A similar pattern occurred at Unzen (1991-1993) with the collapse of a multi-lobed dome creating pyroclastic flows (Kaneko et al. 2002). Santiaguito has lava flow collapses and smaller scale partial dome collapses rather frequently (yearly to every few years). This pattern is a great concern at Santiaguito for much of the collapse material is moved down stream of the volcano creating lahars, hyperconcentrated flows, and floods.

Overall the comparison of rates shown in Table 4-2 and Figure 4.2 shows that short-lived (one to several years) dome extrusion events have extrusion rates that are an order of magnitude higher than the Santiaguito average, and similar to the higher extrusion rates that last for only a few years. Santiaguito has a larger volume and much 
longer duration than many other modern dome examples, while all domes exhibit some form of unsteady flow (Barmin et al. 2002).

After the endogenous to exogenous shift occurred in the 1960-70's, the block lava flow lengths increased, while the $\mathrm{SiO}_{2}$ content dropped by $2 \mathrm{wt} \%$ since 1970 (Rose, 1987; Harris et al. 2003). In spite of this compositional change, we have seen a decreasing extrusion rate (Figure 4.2), which is possibly due to an exhausted and less pressurized chamber, where more mafic magma is being erupted (Harris et al. 2003).

\subsection{DEM Errors}

Errors within a DEM can significantly affect the final analysis for elevation and volume studies. Some other factors which may affect the DEMs are tree canopies, uplift, erosion, and other systematic and random errors relating to data collection and interpolation. Tree canopies can be a source of error in aerial photographs, due to the elevation of the canopy recorded and not the ground (Stevens et al. 1997). For this study, tree canopies may introduce error in regions outside of the volcanic zone, but much of the analysis was conducted on the volcanic dome or in areas of activated flood

plains and therefore we believe the effects of tree canopies to be minimal. For this study we do not consider regional uplift effects which may occur along the volcanic front, because we have no estimates to help constrain them. Similarly, we have not considered the regional sedimentation that is demonstrably underway, transporting sediments from the volcanic highland to the coastal slope and coastal plain; therefore this is not included in the error analysis.

In this study, points obtained from the contour lines or from the aerial photography were used as the reference points. There was no independent set of 
reference points to determine an RMSE for each DEM. The reference points are a good indicator for the error due to interpolation, which is what was used for this study. Ideally independent ground control points (GCP's) would be used which have a higher accuracy level than the DEMs used here, resulting in reduced DEM errors. The method used here was a conservative approach, yielding higher errors than may actually exist in the DEMs and further analysis would have to be done to obtain more accurate error estimates.

\subsection{Pacaya}

The emplacement of volcanic products (i.e. lava flows, spatter and proximal tephra deposits) due to the eruptive activity of the MacKenney Cone at Pacaya since 1961 are clearly recognizable in our results. Because MacKenney Cone’s east side is buttressed by an earlier cone, most of the 1961-01 activity has taken place on the west

side of the MacKenney Cone yielding a volume change of $0.21 \pm 0.05 \mathrm{~km}^{3}(0.17 \pm 0.04$ $\mathrm{m}^{3} \mathrm{~s}^{-1}$ ) (Figure 3.5). Pacaya is dominated by Strombolian activity, lava flows and tephra fall. The tephra falls are not accurately reflected in this analysis since we believe that significant volume of the tephra falls were distributed outside of the masked DEM volume change region. Major effusive phases occurred in 1961, 1965-1989, and 19902000 (Matías, 2008 (unpublished data)). Much of the 1980’s through 2000 flows are overlain on one another to the north-west of the MC, but the January 10-16, 2000 flow is shown (Figure 3.5) directly north of the cone (BGVN, 2000). Pacaya poses various volcanic hazards including lava flows, lava bombs, spatter, and tephra fall. This study has shown where much of the current activity has taken place, north of the Mackenney Cone, and can be used to determine the location of future hazards. In addition, the possibilities of debris avalanches or volcanic edifice sector collapses are a concerning 
hazard for the future (Vallance et al. 1995). Continued monitoring of the elevation and volume change at Pacaya could help with determining future volcanic hazards.

The extrusion rates of four other basaltic convergent plate boundary volcanoes are compared with Pacaya (Table 4-3 and Figure 4.3).

Table 4-3 Lava volume and extrusion rates for basaltic volcanoes

\begin{tabular}{|c|c|c|c|c|c|}
\hline & Pacaya $^{\mathrm{a}}$ & Stromboli $^{\mathrm{b}}$ & Izalco $^{c}$ & Cerro Negro $^{\mathrm{d}, \mathrm{e}}$ & Fuego ${ }^{f, g}$ \\
\hline Period of dome growth & & & & & \\
\hline From & Mar-61 & Feb-34 & 1770 & Apr-1850 & 1932 \\
\hline To & Feb-01 & Present & 1974 & Aug-99 & 1979 \\
\hline Duration (yr) & 40 & 73 & 204 & 149 & 47 \\
\hline Lava Volume $\left(\mathrm{m}^{3}\right)$ & $2.1 \times 10^{8}$ & $\begin{aligned}> & 2.6 \mathrm{x} \\
& 10^{6}\end{aligned}$ & $2 \times 10^{9}$ & $4 \times 10^{7}$ & $7 \times 10^{8}$ \\
\hline $\begin{array}{l}\text { Average eruption rate } \\
\left(\mathrm{m}^{3} \mathrm{~s}^{-1}\right)\end{array}$ & $\sim 0.17$ & 0.001 & 0.31 & 0.008 & 0.5 \\
\hline $\mathrm{SiO}_{2}$ Content & $47-52 \%$ & $52-53 \%$ & $53-56 \%$ & $48-50 \%$ & $50-54 \%$ \\
\hline
\end{tabular}

a This paper, ${ }^{\mathrm{b}} \mathrm{GVN}, 2007,{ }^{\mathrm{c}}$ Carr et al. 1981, ${ }^{\mathrm{d}} \mathrm{GVN}, 2007 \mathrm{~b},{ }^{\mathrm{e}}$ Carr et al. 2003, ${ }^{\mathrm{f}}$ Martin and Rose, 1981, ${ }^{\mathrm{g}}$ Roggensack, 2001

Of the four examples in Table 4-3, the eruption style of Pacaya matches best that of Izalco, which was continuously active from about 1770 until 1960, and the two volcanoes have similar eruption rates. Stromboli and Cerro Negro, two other basaltic volcanoes with frequent activities, erupt less prolifically. Stromboli has been continually active at a low rate for the past 3000 years at least, while Cerro Negro has had several brief Strombolian events each decade since 1870 . Fuego is another nearby basaltic center which erupts frequently. Its eruption rate has been estimated at $\sim 0.5 \mathrm{~m}^{3} \mathrm{~s}^{-1}$ by Martin and Rose (1981). The higher vertical stature of Fuego (3770 m vs. 2500 m for Pacaya) and its possibly higher eruption rate may partly reflect higher volatile content of its magma 
(Roggensack, 2001). Pacaya has a much higher eruption rate than Cerro Negro and Stromboli, and has similar eruption rates to Fuego and Izalco, although Izalco erupted more over a longer time period (Figure 4.3).

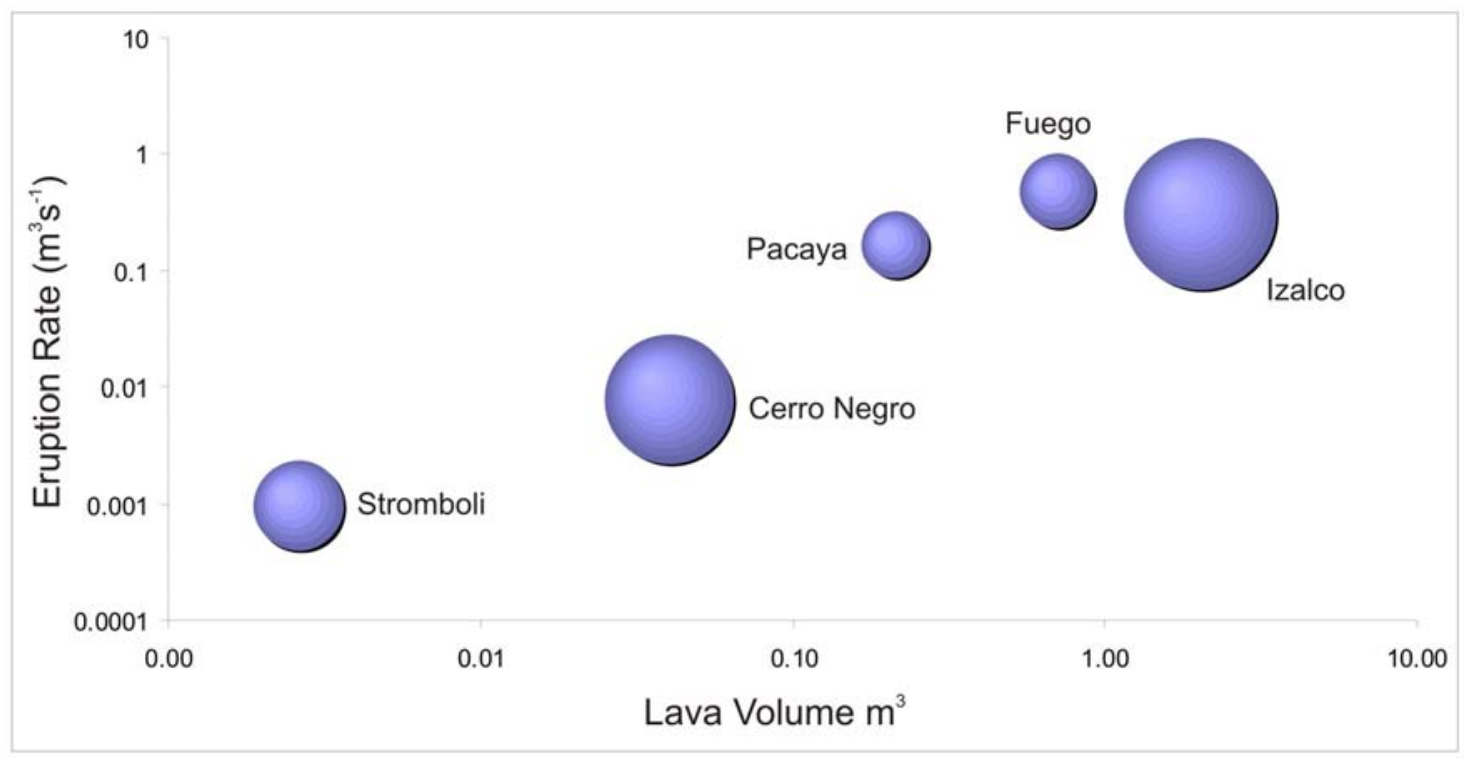

Figure 4.3 Graph showing lava volume vs. eruption rate. The area of circles plotted are proportional to the duration of activity measured.

Pacaya is marked by thin lava flows which require high resolution DEM data to be accurately resolved. A detailed map of Pacaya’s activity since 1961 is being compiled using orthophoto data with 1m resolution (O. Matias, MS thesis, MTU, in prep.). 


\section{Conclusion}

DEM subtraction is an accurate method for determining elevation change and extrusion rate at active effusive volcanoes. This study resulted in more accurate estimates of volume changes and eruptive flux rates at Santiaguito and Pacaya volcanoes. Our results compare well with previous estimates derived from field methods and Landsat satellite images at Santiaguito (Rose et al. 1970; Rose 1972b; 1987; Harris et al. 2003), but the new results have smaller errors. The DEM analysis of Santiaguito matches the patterns of blocky lava flow activity, that were reported by field studies at the dome from 1954-2001. The total volume erupted at Santiaguito from 1922-2001 is estimated at $1.48 \pm 0.19 \mathrm{~km}^{3}$. This value is believed to be a minimum because some volume of erupted materials is rapidly transported southward by dome collapses and sedimentation is unmeasured here and dispersed volcanic ash is also not estimated. To determine the effect of volcanic sedimentation, higher accuracy DEMs, and more datasets at varying time intervals should be analyzed. This will further quantify the influx/outflux of volcanic sediment from Santiaguito and can be added to the overall erupted volume of Santiaguito. Comparison of Santiaguito with other domes, reveal that short lived dome extrusion events have extrusion rates which are an order of magnitude higher than that of Santiaguito. Santiaguito has a much larger volume and much longer duration than most modern dome examples. The DEM volume difference estimates at Pacaya from 1954-2001 were found to be $0.21 \pm 0.05 \mathrm{~km}^{3}$, created by lava flow and spatter deposition associated with the development of the Mackenney Cone. Comparison of Pacaya with other basaltic volcanoes, reveal that Pacaya has similar eruption rates as Fuego and Izalco, two basaltic volcanoes with prolific activity records. 
Ideally GCP's would be used to obtain a more accurate DEM error; therefore greatly decreasing the error in the volcanic regions, as well as regions downslope. Through the analysis of DEMs we have calculated elevation and volume change at both Santiaguito and Pacaya, which revealed areas of deposition and erosion. Due to much of this material moving downslope to populated areas, these changes should be monitored to prepare for future volcanic hazards. DEM analysis proved successful in determining elevation change with improved error estimates over a $\sim 50$ year period at both Santiaguito and Pacaya and the same methodology can be applied to many other volcanoes to map and predict volcanic hazards. 


\section{References}

Baldi P., Bonvalot S., Brioles P., Coltelli M., Gwinner K., Marsella M., Puglisi G., Remy D. (2002) Validation and comparison of different techniques for the derivation of digital elevation models and volcanic monitoring (Vulcano Island, Italy). Int. J. Remote Sensing 23:4783-4800.

Barmin A.O, Melnik O., Sparks R.S.J. (2002) Periodic behavior in lava dome eruptions. EPSL 199: 173-184.

BGVN (1999) Pacaya, Smithsonian Inst Bull Global Volcanism Network 24(12). http://www.volcano.si.edu/world/volcano.cfm?vnum=1402-

11=\&volpage=var\#bgvn_2412

BGVN (2000) Pacaya, Smithsonian Inst Bull Global Volcanism Network 25(01). http://www.volcano.si.edu/world/volcano.cfm?vnum=1402-

11=\&volpage=var\#bgvn_2501

Carr M.J. and Pontier N.K. (1981) Evolution of a young parasitic cone towards a mature central vent; Izalco and Santa Ana volcanoes in El Salvador, Central America. J Volcanol Geotherm Res 11:277-292.

Carr M. J., Feigenson M. D., Patino L. C.,Walker J.A. (2003) Volcanism and Geochemistry in Central America: Progress and Problems. In: Inside the Subduction Factory. John M. Eiler (ed) Geophysical Monograph v. 138; p.153-179.

Carr M.J, Patino L.C., Feigenson M.D. (2007) Petrology and geochemistry of lavas. In: Central America: Geology, Resources and Hazards. Bundschuh J. and Alvarado G.E. (ed) T.F. Taylor, Chapter 22.

Conway F.M, Diehl J.F., Matías O. (1992) Paleomagnetic constraints on eruption patterns at Pacaya composite volcano, Guatemala. Bull Volcanol 55: 25-32

Dehn J, Bailey J.E., Dean K.G., Skoog R., Valcic L. (2006) Satellite based extrusion rates for the 2006 Augustine eruption. American Geophysical Union, Fall Meeting 2006, abstract \#V42B-02

DeMets C. (2001) A new estimate for present-day Cocos-Caribbean plate motion: Implications for slip along the Central American volcanic arc. Geophys Res. Letters 28: 4043-4046.

Eggers A.A. (1971) The geology and petrology of the Amatitlán quadrangle, Guatemala. Ph.D. Thesis, Dartmouth College 221 p. 
Eggers A.A. (1983) Temporal Gravity and Elevation Changes at Pacaya Volcano, Guatemala. , J Volcanol Geoth Res 19: 223-237

Escobar, R P, O Matias and W I Rose, 2008, Geologic map of Santiaguito Volcano, 2006, IAVCEI Iceland Meeting Abstract

Fink J. H (1987) The emplacement of silicic domes and lava flows. GSA Special Paper 212 1-16.

GVN (2007) Cerro Negro, Smithsonian Inst Bull Global Volcanism Network: Eruption history.http://www.volcano.si.edu/world/volcano.cfm?vnum=1404-07=\&volpage=erupt

GVN (2007) Stomboli, Smithsonian Inst Bull Global Volcanism Network: Eruption history. http://www.volcano.si.edu/world/volcano.cfm?vnum=0101$04=\&$ volpage $=$ erupt

GVN (2008) Pacaya, Smithsonian Inst Bull Global Volcanism Network: Eruption history. http://www.volcano.si.edu/world/volcano.cfm?vnum=1402-11=\&volpage=erupt

Harris A.J.L, Rose W.I, Flynn L.P (2003) Temporal trends in lava dome extrusion at Santiaguito 1922-2000. Bull Volcanol 65:77-89.

Harris, A.J.L., Flynn L.P, Matías O., Rose W.I., Cornejo J. (2004), The evolution of an active silicic lava flow field: an ETM+ perspective, J Volcanol Geoth Res 135: 147-168.

Harris A.J.L., Vallance J.W., Kimberly P.G., Rose W.I., Matías O., Flynn L.P.,Garbeil H. (2006) Downstream aggradation owing to lava dome extrusion and rainfall runoff at Volcan Santiaguito, Guatemala, G S A Special Paper 412: 85-104.

Hutchinson, M. F. (1993) Development of a continent-wide DEM with applications to terrain and climate analysis. In: Environmental Modeling with GIS. Goodchild M.F., Parks B.O., Steyaert L.T. (ed) Oxford University Press. 392-399.

(JICA) Agencia de Cooperación Internacional del Japón, Instituto Geográfico Nacional (IGN), Instituto Nacional de Sismología, Vulcanología, Meteorología e Hidrología (INSIVUMEH), Secretaría de Planificación y Programación de la Presidencia (SEGEPLAN) (2003) Estudio Del Establecimiento De Los Mapas Basicos y Mapas De Amenaza Para El Sistema De Informacíon Geografica De La Republica De Guatemala

Kaneko T., Wooster M.J., Nakada S. (2002) Exogenous and endogenous growth of the Unzen lava dome examined by satellite infrared image analysis. J Volcanol Geoth Res 116: $151-160$ 
Kerle N. (2002) Volume estimation of the 1998 flank collapse at Casita Volcano, Nicaragua: A comparison of photogrammetric and conventional techniques. Earth Surf. Process. Landforms 27:759-772.

Kimberly P.G. (1995) Changing volcaniclastic sedimentary patterns at Santa María volcano, Guatemala, detected with sequential thematic mapper data, 1987-1995. MSc. Thesis, Michigan Technological University: 59 p.

Kitamura S, Matías O. (1995) Tephra stratigraphic approach to the eruptive history of Pacaya volcano, Guatemala. Sci Rpt Tohoku Univ, 7th Ser (Geog): 45: 1-41.

Kuenzi D.W., Horst O.H., McGehee R.V. (1979) Effect of volcanic activity on fluvialdeltaic sedimentation in a modern arc-trench gap, southwestern Guatemala. Geological Society of America Bulletin, Part 1, 90: 827-838.

Martin, D.P and Rose, W.I (1981) Behavioral Patterns of Fuego Volcano, Guatemala. J. Volcanol Geoth Res 10: 67-81.

Miller T.P. (1994) Dome growth and destruction during the 1989-1990 eruption of Redoubt volcano. J Volcanol Geoth Res 62: 197-212.

Nakada S., Shimizu H., Ohta K. (1999) Overview of the 1990-1995 eruption of Unzen Volcano. J Volcanol Geoth Res 89: 1-22.

Power, J.A., Nye, C.J., Coombs, M.L., Wessels, R.L., Cervelli, P.F., Dehn, J., Wallace, K.L., Freymueller, J.T., Doukas, M.P. (2006) The reawakening of Alaska's Augustine Volcano Eos 87: 373, 377.

Rogers R.D., Kárason H, van der Hilst R.D. (2002) Epeirogenic uplift above a detached slab in northern Central America. Geology 30: 1031-1034.

Roggensack, K. (2001) Unraveling the 1974 eruption of Fuego volcano (Guatemala) with small crystals and their young melt inclusions. Geology 10: 911-914.

Rose W.I., Stoiber R.E., Bonis S.B. (1970) Volcanic activity at Santiaguito Volcano, Guatemala, June 1968-August 1969. Bulletin Volcanologique 34: 295-307.

Rose, W. I. (1972a) Notes on the 1902 eruption of Santa María Volcano, Guatemala, Bull. Volc., 36: 29-45.

Rose, W. I., (1972b) Santiaguito Volcanic Dome, Guatemala, Geol. Soc. Amer. Bull., 83: 1413-1434.

Rose, W. I. (1973) Pattern and mechanism of volcanic activity at the Santiaguito volcanic dome, Guatemala, Bull. Volc., 37: 73-94 
Rose, W. I. (1987), Volcanic activity at Santiaguito Volcano, 1976- 1984. Geol. Soc. Amer. Spec. Paper, 212 The Emplacement of Silicic Domes and Lava Flows, ed. by J. Fink) 17-27.

Rowland S.K., MacKay M.E., Garbeil H., Mouginis-Mark P.J. (1999) Topographic analyses of Kilauea Volcano, Hawai’ I, from interferometric airborne radar. Bull Volcanol 61:1-14.

Sapper K. (1903) Der ausbruch des vulkans Santa María en Guatemala. Centralblatt f. Mineral., Geol., und Palaont, p. 33-44

Sapper K. (1926) Die Vulkanishe Tatigheit in Mittelamerika im 20 Jahrhundert. Zeitschrift für Vulkanologie, 9, 156.

Sapper, K., Termer, F. (1930), Der Ausbruch des Vulkans Santa María in Guatemala vom 2-4 November 1929. Zeitschrift für Volkanologie 13: 73-101.

Scott W.E., Sherrod D.R., Gardner C.A. (In Press) Chapter 1: Overview of 2004 to 2005, and continuing, eruption of Mount St. Helens, Washington. U.S Geological Survey Professional Paper (A volcano rekindled: The first year of renewed eruption at Mount St. Helens, 2004-2006, ed. by Sherrod D.R., Scott W.E., Stauffer) 1-16.

Shearer J.W. (1990) The accuracy of digital terrain models In: Terrain modeling in surveying and civil engineering by Petrie G, Kennie G (eds). Wiley, London.

Simkin T., Siebert L. (1994) Volcanoes of the world. Geoscience Press, Tuscon

Siswowidjoyo S., Suryo I., Yokoyama I. (1995) Magma eruption rates of Merapi volcano, Central Java, Indonesia, during one century (1890-1992). Bull Volcanol. 57:111-116.

Steinwand D.R., Hutchinson J.A., Snyder J.P. (1995) Map projections for global and continental data sets and an analysis of pixel distortion caused by reprojection. Photogramm. Eng. Remote Sens. 61: 1487-1497.

Stevens N.F., Murray J.B., Wadge G. (1997) The volume and shape of the 1991-1993 lava flow field at Mount Etna, Sicily. Bull Volcanol. 58: 449-454.

Stevens N.F., Wadge G., Murray J.B. (1999) Lava flow volume and morphology from the digitized contour maps: a case study at Mount Etna, Sicily. Geolomorphology 28: 251-261.

Swanson D.A., Dzurisin D., Holcomb R.T., Iwatsubo E.Y., Chadwick Jr. W.W., Casadevall T.J., Ewert J.W., Heliker C.C. (1987) Growth of the lava dome at Mount St. 
Helens, Washington (USA) 1981-1983. Geol. Soc. Amer. Spec. Paper, 212 (The Emplacement of Silicic Domes and Lava Flows, ed. by J. Fink) 1-16.

U.S. Geological Survey (USGS) Cascades Volcano Observatory (2001) colomba_hp = 1:50,000-scale hypsography (contours) for Quetzaltenango quadrangle, Guatemala. Metadata.

Wadge G., Mattioli G.S., Herd R.A. (2006) Ground deformation at Soufriere Hills Volcano, Montserrat during 1998-2000 measure by radar interferometry and GPS. J Volcanol Geotherm Res 152: 157-173.

Watts R.B., Herd R.A., Sparks S.J., Young S.R, (2002), Growth patterns and emplacement of the andesitic lava dome at Soufriere Hills Volcano, Montserrat. Geol. Soc. Of London, 21 (The Eruption of Soufriere Hills Volcano, Montserrat, from 1995 to 1999, ed. By T.H. Druitt \& B.P. Kokelaar) 115-152.

Williams S.N., Self S. (1983) The October 1902 Plinian eruption of Santa María Volcano, Guatemala. J Volcanol Geotherm Res 16:33-56

Wunderman, R.L. and Rose W.I. (1984) Amatitlán, an actively resurging caldera $10 \mathrm{~km}$ south of Guatemala City. J. Geophys. Res. 89: 8525-8539.

Vallance J.W., Siebert L, Rose Jr. W.I., Girón J.R., Banks N.G. (1995) Edifice collapse and related hazards in Guatemala. J Volcanol Geoth Res 66: 337-355.

Vessell, R.K., Davies, D.K., (1981) Nonmarine Sedimentation in an Active Fore Arc. Basin, S.E.P.M. Spec. Publ. 31, 31-45.

Voight B., Constantine E.K., Siswowidjoyo S., Torley R. (2000) Historical eruptions of Merapi Volcano, Central Java, Indonesia, 1768-1998. J. Volcanol Geoth Res 100:69138. 


\section{Appendix}

I. DEM differencing/error instructions using ArcGIS 9.0. Appendix may be accessed at http://www.geo.mtu.edu/ ksdurst/Thesis/DEMProcedures.html and is also attached in a CD (html and jpeg) with this thesis.

II. ASTER DEM and differencing analysis. Although this research is not presented in this thesis, detailed analysis and instructions may be accessed at http://www.geo.mtu.edu/ ksdurst/Thesis/ASTER.html and is also attached in a CD (html and jpeg) with this thesis. 